\title{
An ethanol extract of Iris nertschinskia induces p53-dependent apoptosis in the MCF7 human breast cancer cell line
}

\author{
JAE-SIK SHIN ${ }^{1,2^{*}}$, SEUNG-WOO HONG ${ }^{1 *}$, JIN-GYUN LEE ${ }^{7}$, YOUNG-MIN LEE $^{3}$, DAE-WON KIM ${ }^{4}$, \\ JEE-EUN KIM ${ }^{8}$, DA-JUNG JUNG ${ }^{8}$, SUNG-KWAN AN ${ }^{2}$, NAM-JOO HONG ${ }^{5}$, \\ DAEJIN KIM ${ }^{6}$, DONG-HOON JIN ${ }^{1}$ and SOK-YOUNG LEE ${ }^{3}$
}

\author{
${ }^{1}$ Institute for Innovative Cancer Research, ASAN Medical Center, Songpa-Gu, Seoul 138-736; ${ }^{2}$ Department of Microbial \\ Engineering, Konkuk University, Seoul 143-701; ${ }^{3}$ PGR Assessment and Utilization Lab, National Agrobiodiversity \\ Center (RDA Genebank), Suwon, Gyeonggi-do; ${ }^{4}$ Bio Research Center, Yeasan-kun, ChoongChungnam-do; \\ ${ }^{5}$ School of Biotechnology, Yeungnam University, Gyungsan, Gyungbuk 712-749; ${ }^{6}$ Department of Anatomy, \\ College of Medicine, Chung-Ang University, Seoul; ${ }^{7}$ College of Pharmacy and Research Institute \\ of Pharmaceutical Science, Seoul National University, Seoul 151-742; ${ }^{8}$ Department of Anatomy, \\ Seoul National University College of Medicine, Jongro-Gu, Seoul, Republic of Korea
}

Received July 5, 2010; Accepted November 26, 2010

DOI: 10.3892/ijmm.2011.599

\begin{abstract}
Iris nertschinskia, an ornamental plant, is utilized in traditional East Asian medicine for the treatment of skin diseases. However, the biological activity underlying its therapeutic effects remains to be established. In this study, we investigated the anti-tumor effect of the plant extract on MCF7 human breast cancer cells. An ethanol extract of Iris nertschinskia triggered cell death in a dose-dependent manner. Moreover, treatment with the extract promoted p53 phosphorylation in MCF7 cells. Increased phosphorylation of $\mathrm{p} 53$, in turn, led to induction of Bax protein, a key regulator of p53-dependent apoptotic cell death, as well as of caspase-7 cleavage in MCF7 cells. Consistently, cells treated with p53-specific siRNA or the caspase inhibitor, Z-VAD, resisted apoptotic cell death induced by the Iris nertschinskia extract. Our results suggest that p53 sensitizes tumor cells to the ethanol extract of Iris nertschinskia by Bax protein induction and caspase-dependent apoptosis.
\end{abstract}

Correspondence to: Dr Dong-Hoon Jin, Institute for Innovative Cancer Research, ASAN Medical Center, Asanbyeongwon-gil, Songpa-Gu, Seoul 138-736, Republic of Korea

E-mail: inno183@amc.seoul.kr

Dr Sok-Young Lee, PGR Assessment and Utilization Lab, National Agrobiodiversity Center (RDA Genebank), 441-707, Suin-ro 150, Kwonson-gu, Suwon, Gyeonggi-do, Republic of Korea

E-mail: 1sy007@rda.go.kr

*Contributed equally

Key words: Iris nertschinskia, p53, Bax, caspase-7, apoptosis

\section{Introduction}

A number of natural compounds from oriental herbs and plants have been isolated for the treatment of diverse human diseases (1-5). In particular, a variety of Iris species are potent anti-cancer agents (6-10). For example, Iris tectorum, introduced as a remedy in the first Chinese monograph on herbal medicine, induces cell cycle arrest and apoptosis in MCF7 and C32 cell lines (6,7). Additionally, Iris germanica and Iris missouriensis display anti-tumor activities $(9,10)$.

Iris nertschinskia is an ornamental plant found in Korea, China, Japan and Eastern Siberia. The plant is traditionally used in East Asian medicine for the treatment of sore throat, skin disease, depilatory disease, and canities. However, no therapeutic effects of this plant on cancer have been reported to date.

Extracts from plants or herbs induce apoptosis (programmed cell death), in cancer cells (11-13). Apoptosis is triggered by cellular stress, which may affect organelles, including the nucleus, endoplasmic reticulum (ER), lysosomes and mitochondria (14). The tumor suppressor protein p53, plays a key role in the response of cellular organelles to stress $(15,16)$. p53 protein triggers apoptosis via changes in mitochondrial membrane permeabilization through induction of transcriptional targets, such as Bax $(17,18)$. Additionally, expression of functional p53 in various p53-deficient cancer cell lines results in apoptosis $(19,20)$. Evidently, p53 is an important factor in regulating the responses of host cells, and thus is applicable to cancer therapy $(15,17)$.

In this study, we investigated the anti-tumor effects of an ethanol extract of Iris nertschinskia and the underlying mechanisms involved. In particular, we focused on the functional status of p53. Initially, we observed that the ethanol extract of Iris nertschinskia induced apoptosis in MCF7 cells expressing the wild-type $p 53$ gene. This finding led us to investigate its effects on p53 functional status. Our data clearly indicate that 
ethanol extracts of Iris nertschinskia exert p53-dependent chemosensitivity.

\section{Materials and methods}

Cell culture. MCF7, a human breast carcinoma cell line, was maintained in DMEM supplemented with $10 \%$ FBS (Life Technologies, Inc., Grand Island, NY) and penicillinstreptomycin $(50 \mathrm{U} / \mathrm{ml})$.

Cell cytotoxicity. Cell viability was determined using trypan blue exclusion by counting at least 500 cells in each culture. Cells were treated with $10,20,50$ or $100 \mu \mathrm{g} / \mathrm{ml}$ of the Iris nertschinskia ethanol extract for $24 \mathrm{~h}$, and live and dead cells were counted.

Preparation of ethanol extracts of Iris nertschinskia. Iris nertschinskia (50 g) was extracted with ethanol (100\%, $500 \mathrm{ml})$ for $18 \mathrm{~h}$ at RT to produce $24 \mathrm{~g}$ of solid extract. The ethanol extract was condensed by decompression concentration and suspended in DW. The suspended extract was frozen at $-70^{\circ} \mathrm{C}$ and dried. The resulting powder, a yellow solid, was suspended into DMSO.

HPLC and MS analysis. The HPLC system consisted of two L-7100 pumps (Hitachi, Japan) coupled with an L-4000 UV detector (Hitachi) and the Sedex evaporative light scattering detector (ELSD, Sedere, France). Phenomenex Gemini $\mathrm{C}_{18}$ columns were used for the isolation and purity assessment of the compounds (a $5 \mu \mathrm{m}, 250 \times 10 \mathrm{~mm}$ and a $5 \mu \mathrm{m}, 250 \times 4.6 \mathrm{~mm}$ column, respectively). MS spectra of the isolated compounds were recorded using the JMS-700 Mass Spectrometer (Jeol, Japan).

RNA interference. Human breast cancer cells were transiently transfected with scrambled siRNA (5'-GCC GGG UGU UUC UAG GAA AGG AUU U-3') (Samchully Pharm Co. Ltd.) or p53 siRNA (5'-GAC TCC AGT GGT AAT CTA C-3') using Lipofectamine $^{\mathrm{TM}}$ RNAiMAX (Invitrogen, Carlsbad, CA).

Cell cycle analysis. For DNA content analysis, $1 \times 10^{6}$ cells were harvested by trypsinization and fixed by rapid submersion in $1 \mathrm{ml}$ cold $70 \%$ ethanol. After fixation at $-20^{\circ} \mathrm{C}$ for at least $1 \mathrm{~h}$, cells were pelleted, resuspended in $1 \mathrm{ml}$ staining solution $(50 \mu \mathrm{g} / \mathrm{ml}$ propidium iodide, $50 \mu \mathrm{g} / \mathrm{ml}$ RNase, $0.1 \%$ Triton $\mathrm{X}-100$ in citrate buffer, $\mathrm{pH} 7.8$ ), and washed with PBS. Fluorescence-stained cells were transferred to polystyrene tubes with cell strainer caps (Falcon), and sorted using a fluorescence-activated cell sorter (FACS) (BD FACSCalibur ${ }^{\mathrm{TM}}$ ).

Western blot analysis. Cell lysates were prepared with RIPA lysis buffer (50 mM Tris- $\mathrm{HCl}, \mathrm{pH} 7.5,50 \mathrm{mM} \mathrm{NaCl}, 1 \mu \mathrm{M}$ EGTA, 1\% Triton X-100) containing a protease inhibitor cocktail. Protein concentrations in extracts were determined using the Bradford assay, and $30 \mu \mathrm{g}$ of total cell protein per sample were separated by SDS-PAGE and transferred to a PolyScreen membrane (NEN, Boston, MA). Membranes were blocked with 5\% nonfat dry milk in TBST buffer $(20 \mathrm{mM}$ Tris- $\mathrm{HCl}, \mathrm{pH} 7.4,150 \mathrm{mM} \mathrm{NaCl}, 0.1 \%$ Tween-20) and probed with one of the following antibodies: anti-p53 (Santa Cruz
A

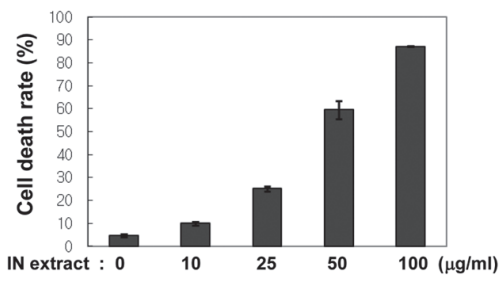

B

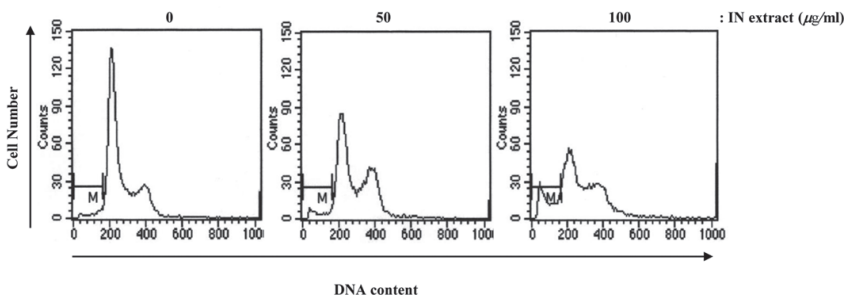

Figure 1. The ethanol extract of Iris nertschinskia induces apoptotic cell death in the human breast cancer cell line, MCF7. (A) Cells were treated the indicated doses of the ethanol extract of Iris nertschinskia, and the cell numbers were counted at $24 \mathrm{~h}$. Cell death was determined by counting the number of trypan blue-stained cells. (B) The cell cycle was analyzed as described in Materials and methods. Each point represents the average result of three independent experiments.

Biotechnology, Santa Cruz, CA), anti-phospho-p53 (Cell Signaling Technology, Beverly, MA), anti- $\gamma$-tubulin, anticaspase-7 and anti-Bax (Santa Cruz Biotechnology). Following incubation with horseradish peroxidase-conjugated goat antimouse and goat anti-rabbit secondary antibodies, blots were developed with an enhanced chemiluminescence detection kit (Amersham, Buckinghamshire, UK).

\section{Results}

Ethanol extract of Iris nertschinskia induces cell death in the MCF7 cell line. Initially, we examined the effects of the Iris nertschinskia extract on the MCF7 human breast cancer cell line. Cells were treated with various doses $(10,25,50$ or $100 \mu \mathrm{g} / \mathrm{ml}$ ) of the plant extract. Interestingly, we observed a significant increase in cell death in extract-treated MCF7 cultures (Fig. 1A). Flow cytometric analyses revealed a dramatic increase in the number of cells at the sub-G1 phase after exposure to high doses of the extract (50 or $100 \mu \mathrm{g} / \mathrm{ml}$ ) (Fig. 1B). However, cell cycle arrest rather than death was observed with the low doses (10 or $25 \mu \mathrm{g} / \mathrm{ml}$ ). Cells treated with low doses of the ethanol extract accumulated at the G1 phase (data not shown), implying that Iris nertschinskia exerts an anti-tumor effect through cell death induction in the human MCF7 breast cancer cell line.

HPLC analysis of the Iris nertschinskia extract. We performed HPLC and MS analyses to define the material in an ethanol extract of Iris nertschinskia. ELSD-HPLC analysis identified 10 peaks of which the 3 , peak nos. 1,3 , and 10 , had an inhibitory effect on cell proliferation of MCF7 cells (Fig. 2A). Secondly, the 3 peaks were analyzed by GC-MS methods to identify the materials (Fig. 2B). Interestingly, the following three compounds were identified; dihydrovallesiachotamine, [(15 $\beta, 16 \mathrm{E})-16,17,20,21$-tetradehydro-16-(hydroxymethyl)-18- 
A

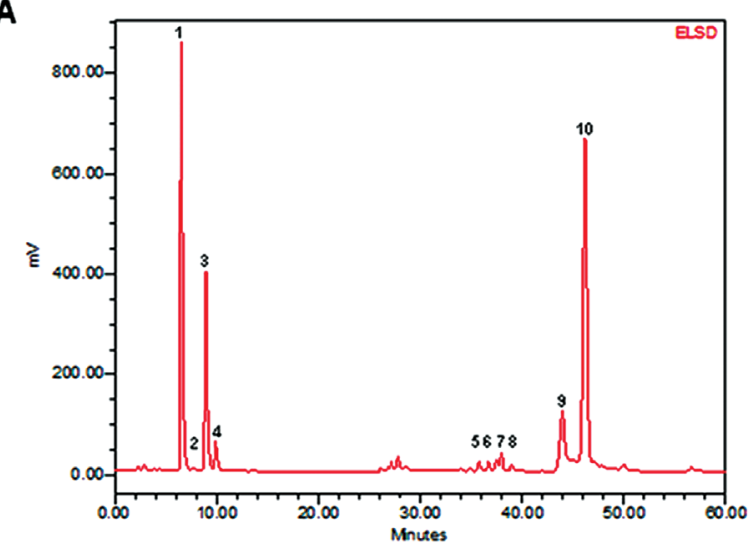

B

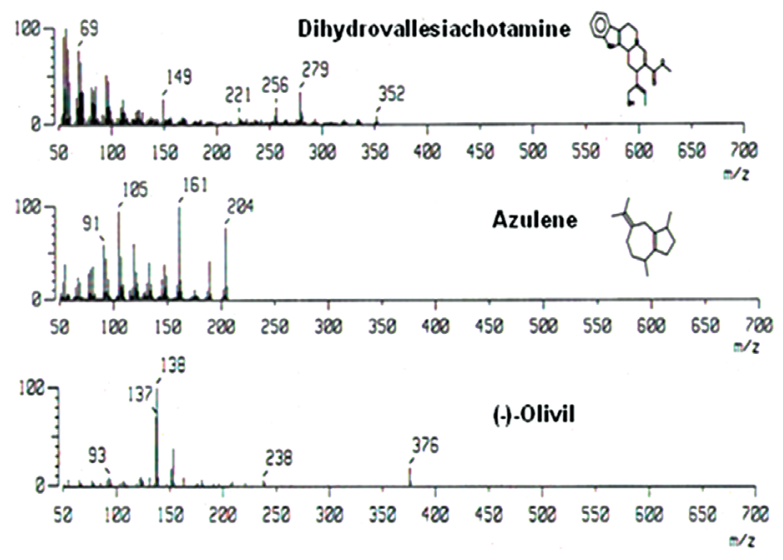

Figure 2. HPLC and MS analysis of Iris nertschinskia. (A) ELSD-HPLC chromatogram of the EtOAC fraction isolated from the Iris nertschinskia ethanol extract. GC-MS analysis of the three fractions isolated by HPLC analysis of Iris nertschinskia ethanol extract. (B) Dihydrovallesiachotamine; (15 $\beta, 16 \mathrm{E})$ 16,17,20,21-tetradehydro-16-(hydroxymethyl)-18-19-secoyohimban-19-oic acid methyl ester]. Azulene, 1,2,3,4,5,6,7,8-octahydro-1,4-dimethyl-7-(1methylethylidene)-,(1S-cis)- azulene; (-)-Olivil.

19-secoyohimban-19-oic acid methyl ester]; Azulene, [1,2,3,4, 5,6,7,8-octahydro-1,4-dimethyl-7-(1-methylethylidene)-,(1Scis)-azulene]; and (-)-olivil. It has been previously reported that azulene and (-)-olivil have the anti-inflammatory and antioxidant effects $(21,22)$ while dihydrovallesiachotamine, an analogue of vallesiachotamine, has cytotoxic activity on cancer cells $(23,24)$.

The ethanol extract of Iris nertschinskia induces phosphorylation of $p 53$ and of target molecules. In view of the apoptotic effect of the Iris nertschinskia extract on MCF7 expressing wild-type p53, we initially examined the p53 functional status in MCF7 cells following exposure to the plant extract. Phosphorylation of p53 (Ser-15) increased gradually and in a dose-dependent manner (Fig. 3A), indicative of an association with p53-induced cell death. Accordingly, we monitored the expression patterns of Bax in cells treated with the extract. The Bax protein level in total lysates exposed to the extract was increased (Fig. 3B). Earlier studies have shown that overexpression of Bax mediated by p53 results in translocation to the mitochondrial outer membrane, and subsequently, to mitochondrial dysfunction (25-27). Moreover, Bax induces cytochrome c release that forms an apoptosome with Apaf-1

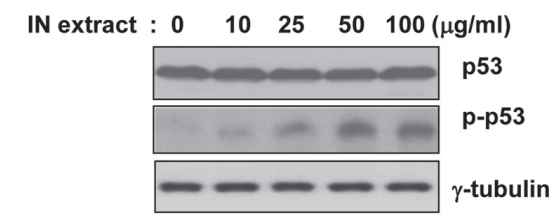

B

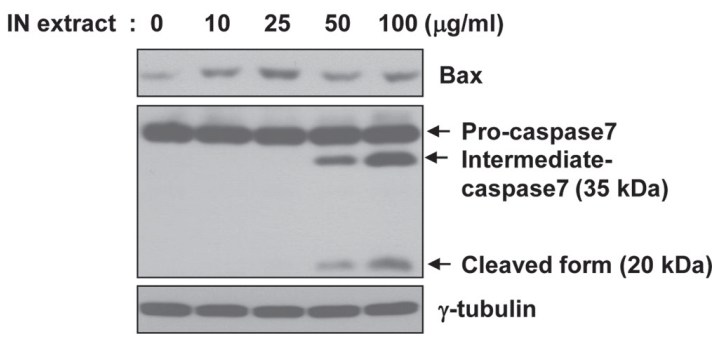

Figure 3. The ethanol extract of Iris nertschinskia (IN) activates p53 and its target molecules. (A) Cells were treated the indicated doses of the ethanol extract of Iris nertschinskia. Whole-cell extracts were prepared and analyzed by Western blotting using anti-p53 and anti-p-p53. (B) The protein level of Bax and the cleavage of caspase-7 (p53-targeted molecules) were analyzed by Western blotting using anti-Bax and anti-procaspase-7 antibodies. $\gamma$-tubulin was used as a loading control.

and procaspase-9, leading to activation of the caspase cascade (28-30). Next, we examined the changes in caspase-7 in MCF7 cells depleted of caspase- 3 or -8 after treatment with the extract (31). Both intermediate and cleaved forms of caspase-7 (Fig. 3B) as well as caspase-9 (data not shown) were present in cells treated with ethanol extracts of Iris nertschinskia. These results suggest that apoptosis induced by the plant extract is associated with the functional status of p53 and its target molecules.

The ethanol extract of Iris nertschinskia induces p53-dependent apoptotic cell death. To confirm that apoptotic cell death induced by the ethanol extract of Iris nertschinskia in MCF7 cells is correlated with functional p53, we examined the effects of silencing endogenous wild-type p53 in MCF7 cells using small interfering RNAs (siRNAs). Cells were transiently transfected with p53 siRNA or scrambled siRNA constructs, followed by treatment with ethanol extracts of Iris nertschinskia in a dose-dependent manner (Fig. 4). Transfection with p53 siRNA suppressed apoptosis induced by the ethanol extract of Iris nertschinskia, whereas scrambled siRNA had no effect (Fig. 4A). To further confirm these results, we evaluated the protein levels of cleaved caspase-7 and Bax. Expression of Bax and cleavage of caspase-7 were suppressed in p53 siRNAtreated, but not in scramble siRNA-treated cells (Fig. 4B). These results are in accordance with the theory that apoptosis induced by an ethanol extract of Iris nertschinskia is related to the functional status of $\mathrm{p} 53$ in MCF7 cells.

The ethanol extract of Iris nertschinskia induces caspasedependent apoptotic cell death. As shown in Figs. 3B and 4B, the ethanol extract of Iris nertschinskia promoted cleavage of caspase-7 in MCF7 cells depleted of caspase-3 (31). For further confirmation of these results, we examined the effects of the pan-caspase inhibitor, Z-VAD. Cells were pre-treated 


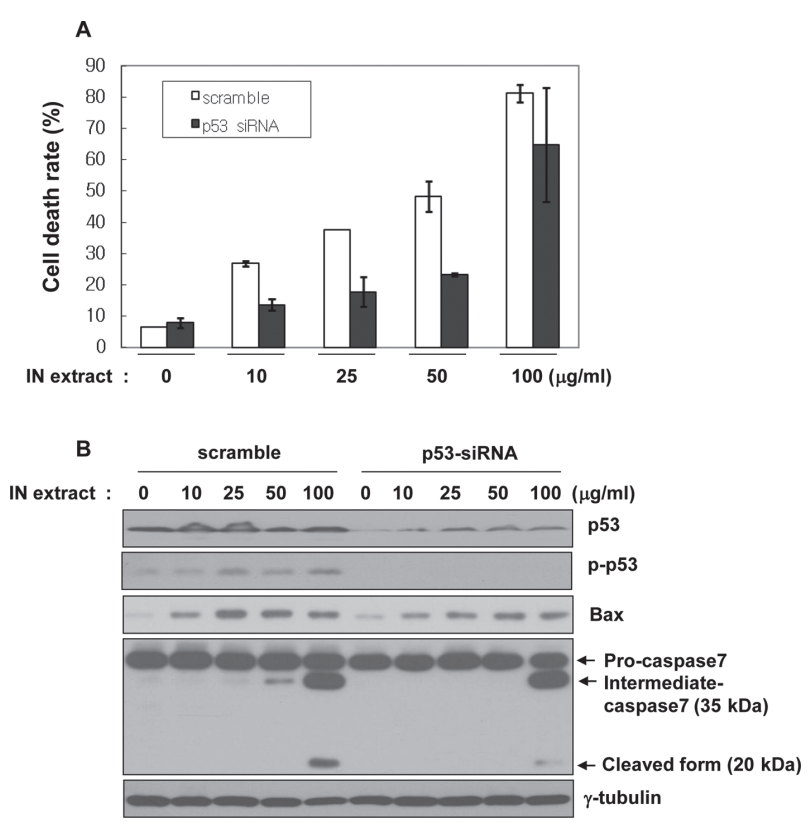

Figure 4. The ethanol extract of Iris nertschinskia (IN) induces p53-dependent apoptotic cell death. (A) Cells were transiently transfected with scrambled siRNA (control) or p53 siRNA $24 \mathrm{~h}$ before treatment with the indicated doses of the ethanol extract of Iris nertschinskia for $24 \mathrm{~h}$. Cell death was determined as for Fig. 1A. (B) Preparation of whole cell lysates from cells transfected with scramble siRNA or p53 siRNA, and analysis by Western blotting using anti-p53, anti-p-p53, anti-Bax or caspase-7 antibodies. $\gamma$-tubulin was used as the loading control.
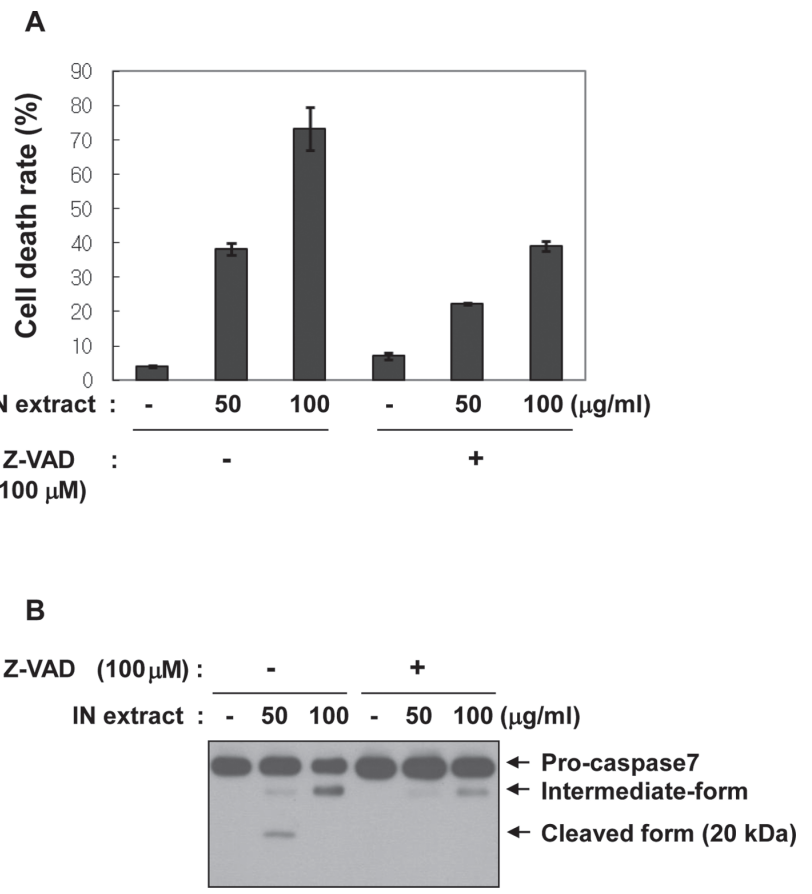

Figure 5. The ethanol extract of Iris nertschinskia (IN) induces caspasedependent apoptotic cell death. (A) Cells were pretreated with $100 \mathrm{mM}$ Z-VAD, a pan-caspase inhibitor, followed by the indicated doses of the Iris nertschinskia extract for $24 \mathrm{~h}$. Cell death was determined as for Fig. 1. (B) Analysis of the effect of Z-VAD on cells by Western blotting using an anticaspase-7 antibody. $\gamma$-tubulin was used as the loading control.

with $100 \mu \mathrm{M}$ Z-VAD, followed by exposure to the extract. Treatment with Z-VAD significantly suppressed apoptotic cell death induced by the plant extract (Fig. 5A). Moreover, changes in caspase-7 were investigated using Western blot analysis. Formation of cleaved $(20 \mathrm{kDa})$ and intermediate caspase-7 $(35 \mathrm{kDa})$ was clearly inhibited (Fig. 5B), implying that the ethanol extract of Iris nertschinskia induces caspase-dependent apoptosis in MCF7 cells.

\section{Discussion}

In this study, we have shown that an ethanol extract of Iris nertschinskia induces apoptotic cell death in the MCF7 human breast cancer cell line. Furthermore, the Iris nertschinskia extract stimulates phosphorylation of p53 at Ser-15, leading to overexpression of Bax protein and caspase-7 cleavage in MCF7 cells. Importantly, transfection of p53 siRNA in cells suppresses apoptosis induced by the plant extract and alters both Bax protein and caspase-7 levels. It appears that the Iris nertschinskia extract confers enhanced sensitivity to cells with functional p53, suggesting that the functional p53 status is correlated with the underlying mechanism of apoptosis.

The major effect of the treatment of MCF7 cells with high concentrations (50 or $100 \mu \mathrm{g} / \mathrm{ml}$ ) of Iris nertschinskia was apoptotic cell death (Fig. 1) while that of low doses (10 or $25 \mu \mathrm{g} / \mathrm{ml}$ ) was to promote accumulation of cells at the G1 phase of the cell division cycle and to induce apoptosis (data not shown). This cellular phenomenon following treatment with low doses of the extract may be related to the functional status of p53. Several studies have shown that $\mathrm{p} 53$ regulates a variety of cellular responses, including cell cycle arrest and apoptosis, after exposure to stress $(15,16,32)$. As shown in Fig. 3, phosphorylation of p53 was additionally stimulated after treatment with low doses of the ethanol extract of Iris nertschinskia. We are currently investigating the detailed mechanisms underlying cell cycle arrest induced by the plant extract at lower doses.

Since the function of p53 in response to cellular stress has generally been established based on its role in the DNA damage response pathway (32), we focused on the functional status of p53. The ethanol extract of Iris nertschinskia induced apoptosis in MCF7 cells containing wild-type p53, as well as phosphorylation of p53 (Figs. 1 and 3). These events were significantly suppressed in p53 siRNA-treated cells (Fig. 4). Consequently, target molecules, such as Bax protein and caspase-7, were clearly affected. Thus, it appears likely that p53 activation in Iris nertschinskia-treated cells is sufficient to elicit a full apoptotic response through overexpression of Bax protein and cleavage of caspase-7 (Figs. 3 and 4). We speculate that the anti-tumor effects of the ethanol extract of Iris nertschinskia on cancer cell lines are correlated with functional status of p53. To further confirm this phenomenon, we are investigating a variety of cancer cell lines that have p53 function. Our findings suggest that the Iris nertschinskia extract induces apoptotic cell death through activation of $\mathrm{p} 53$, and subsequently, induction of Bax protein and caspase-7 cleavage in MCF7, a human breast cancer cell line, thus presenting an attractive cancer treatment option.

\section{Acknowledgements}

This study was supported by the National Agrobiodiversity Center (2009). 


\section{References}

1. Schmidt BM, Ribnicky DM, Lipsky PE and Raskin I: Revisiting the ancient concept of botanical therapeutics. Nat Chem Biol 3: 360-366, 2007

2. Wang JF, Wei DQ and Chou KC: Drug candidates from traditional Chinese medicines. Curr Top Med Chem 8: 1656-1665, 2008.

3. Wargovich MJ, Woods C, Hollis DM and Zander ME: Herbals, cancer prevention and health. J Nutr 131 (Suppl. 11): 3034S-3036S, 2001.

4. Craig WJ: Phytochemicals: guardians of our health. J Am Diet Assoc 97 (10 Suppl. 2): S199-S204, 1997.

5. Pandey RC: Prospecting for potentially new pharmaceuticals from natural sources. Med Res Rev 18: 333-346, 1998.

6. Tan TL and Wen JJ: Pharmaceutical achievement of Shen Nong BenCiao Jing. Chin Pharm J 36: 349-350, 2001

7. Rui F, Houghton PJ and Hylands PJ: Cytotoxic effects of compounds from Iris tectorum on human cancer cell lines. J Ethnopharmacol 118: 257-263, 2008.

8. Klingaman G: Plant of the week: Japanese roof iris, Latin: Iris tectorum. Division of Agriculture, University of Arkansas, Little Rock, Arkansas, USA 2005.

9. Wong SM, Oshima Y, Pezzuto JM, Fong HH and Farnsworth NR: Isolation and characterization of a new from Iris missouriensis. J Nat Prod 49: 330-333, 1986.

10. Wollenweber E, Stevens JF, Klimo K, Knauft J, Frank N and Gerhäuser C: Cancer chemopreventive in vitro activities of isoflavones isolated from Iris germanica. Planta Med 69: 15-20, 2003.

11. Darzynkiewicz Z, Traganos F, Wu JM and Chen S: Chinese herbal mixture PC SPES in treatment of prostate cancer. Int J Oncol 17: 729-736, 2000

12. Kummalue T: Molecular mechanism of herbs in human lung cancer cells. J Med Assoc Thai 88: 1725-1734, 2005.

13. Ji L, Chen Y, Liu T and Wang Z: Involvement of Bcl-xL degradation and mitochondrial-mediated apoptotic pathway in pyrrolizidine alkaloids-induced apoptosis in hepatocytes. Toxicol Appl Pharmacol 231: 393-400, 2008.

14. Green DR and Kroemer G: The pathophysiology of mitochondrial cell death. Science 305: 626-629, 2004.

15. Vazquez A, Bond EE, Levine AJ and Bond GL: The genetics of the p53 pathway, apoptosis and cancer therapy. Nat Rev Drug Discov 7: 979-987, 2008

16. Meulmeester E and Jochemsen AG: p53: a guide to apoptosis. Curr Cancer Drug Targets 8: 87-97, 2008.

17. Galluzzi L, Morselli E, Kepp O, Tajeddine N and Kroemer G: Targeting p53 to mitochondria for cancer therapy. Cell Cycle 7: 1949-1955, 2008.

18. Schuler M and Green DR: Mechanisms of p53-dependent apoptosis. Biochem Soc Trans 29: 684-688, 2001.

19. Yonish-Rouach E, Resnitzky D, Lotem J, Sachs L, Kimchi A and Oren M: Wild-type p53 induces apoptosis of myeloid leukaemic cells that is inhibited by interleukin-6. Nature 352: 345-347, 1991.
20. Shaw P, Bovey R, Tardy S, Sahli R, Sordat B and Costa J: Induction of apoptosis by wild-type p53 in a human colon tumorderived cell line. Proc Natl Acad Sci USA 89: 4495-4499, 1992.

21. Rekka E, Chrrysselis M, Siskou I and Kourounakis A: Synthesis of new azluene derivatives and study of their effect on lipid peroxidation and lipoxygenase activity. Chem Pharm Bull 50: 904-907, 2002

22. Ghogomu-Tih R, Bodo B, Nyasse B and Sondengam BL: Isolation and identification of (-)-olivil and (+)-cycloolivil from Stereospermum kunthianum. Planta Med 51: 464, 1985.

23. Norio A, Toshiaki S, Kayoko F, Yumiko I, Chifumi A, Keiko K, Shinichiro S, Joju H and Kazuo Y: Studies on plants containing indole alkaloids. VIII indole alkaloid glycosides and other constituents of the leaves of Uncaria rhynchophylla MIQ. Chem Pharm Bull 30: 4046-4051, 1982.

24. Atta-ur-Rahman and Sohail M: Isolation of isovallesiachotamine from legumes Rhazya stricta. J Nat Prod 47: 388-389, 1984

25. Finucane DM, Bossy-Wetzel E, Waterhouse NJ, Cotter TG and Green DR: Bax-induced caspase activation and apoptosis via cytochrome c release from mitochondria is inhibitable by Bcl-xL. J Biol Chem 274: 2225-2233, 1999.

26. Wolter KG, Hsu YT, Smith CL, Nechushtan A, Xi XG and Youle RJ: Movement of Bax from the cytosol to mitochondria during apoptosis. J Cell Biol 139: 1281-1292, 1997.

27. Jürgensmeier JM, Xie Z, Deveraux Q, Ellerby L, Bredesen D and Reed JC: Bax directly induces release of cytochrome $\mathrm{c}$ from isolated mitochondria. Proc Natl Acad Sci USA 95: 4997-5002, 1998.

28. Li P, Nijhawan D, Budihardjo L, Srinivasula SM, Ahmad M, Alnemri ES and Wang X: Cytochrome c and dATP-dependent formation of Apaf-1/caspase-9 complex initiates an apoptotic protease cascade. Cell 91: 479-489, 1997.

29. Kobayashi T, Sawa H, Morikawa J, Zhang W and Shiku H: Bax induction activates apoptotic cascade via mitochondrial cytochrome c release and Bax overexpression enhances apoptosis induced by chemotherapeutic agents in DLD-1 colon cancer cells. Jpn J Cancer Res 91: 1264-1268, 2000.

30. Wei MC, Zong WX, Cheng EH, Lindsten T, Panoutsakopoulou V, Ross AJ, Roth KA, MacGregor GR, Thompson CB and Korsmeyer SJ: Proapoptotic BAX and BAK: a requisite gateway to mitochondrial dysfunction and death. Science 292: 727-730, 2001.

31. Onuki R, Kawasaki H, Baba T and Taira K: Analysis of a mitochondrial apoptotic pathway using Bid-targeted ribozymes in human MCF7 cells in the absence of a caspase-3-dependent pathway. Antisense Nucleic Acid Drug Dev 13: 75-82, 2003.

32. Das S, Boswell SA, Aaronson SA and Lee SW: p53 promoter selection: choosing between life and death. Cell Cycle 7: $154-157,2008$ 